\title{
NEW RESEARCH DIRECTIONS IN
} THE INSTITUTION-BASED VIEW

\section{Mike W. Peng}

\section{ABSTRACT}

15 This paper points out new directions for the deepening and broadening of the institution-based view, by drawing on three streams of research with

17 which I have been involved recently: (1) outward foreign direct investment from emerging economies, (2) bankruptcy laws and entrepreneur-

19 ship development, and (3) institution-based research focusing on Africa. Such deepening has been accomplished by enhancing our institution-

21 based understanding of foreign direct investment with a focus on emerging multinationals, while broadening has been done both substantively

23 by probing into the impact of bankruptcy laws on entrepreneurship development around the world and geographically by calling for enhanced

25 research attention on Africa via an institution-based lens.

Keywords: Institution-based view; outward foreign direct investment; emerging economies; emerging multinationals; bankruptcy laws; Africa

Multidisciplinary Insights from New AIB Fellows 
There can be little doubt that institution-related issues have become more important (p. 19) ... I would hope that the fraternity of IB scholars will place these issues at the top of their research agenda over the next decade or so. If we do not do so, I believe that we will be failing both our students and the international community that we seek to serve (p. 24).

John Dunning (2004)

9 The institution-based view is a theoretical perspective in international business (IB) that suggests that the success and failure of firms around the

11 world are enabled and constrained - at least in part - by institutions (Peng, 2014, p. 35). The "institution-based view of strategy" label was first

13 advocated by me in the Asia Pacific Journal of Management in 2002. While I can claim credit for coining this expression, institution-based research in

15 strategy, organization and IB is a broad scholarly movement with numerous participants (Ahn \& York, 2011; Ahuja \& Yayavaram, 2011; Carney,

17 Gedajlovic, \& Yang, 2009; Chari \& David, 2012; Dau, 2012; Hoskisson, Wright, Filatotchev, \& Peng, 2013; Khoury \& Peng, 2011; Kim, Kim, \&

19 Hoskisson, 2010; Liu, Yang, \& Zhang, 2012; Lu, Tsang, \& Peng, 2008; Mahlich, 2010; Meyer, Estrin, Bhaumik, \& Peng, 2009; Meyer \& Peng,

21 2005; Peng, 2003, 2012, 2013; Pinkse \& Kolk, 2012; Ritchie \& Melnyk, 2011; Shinkle \& Kriauciunas, 2012).

23 While institutionally oriented scholars are naturally interested in advancing this view, it is interesting to note that a leading IB scholar John

25 Dunning, who was not known to be an "institutionalist" and whose career spanned five decades, strongly promoted the institution-based view toward

27 the end of his career (Dunning, 2004; Dunning \& Lundan, 2008). If the institution-based research was a relatively peripheral research stream two

29 decades ago, it has gained tremendous legitimacy and experienced enormous growth lately as a result of collective efforts undertaken by likeminded scholars. ${ }^{1}$

The origins and emergence of the institution-based view have been dis-

33 cussed in a series of earlier review papers by Peng (2005), Peng, Wang, and Jiang (2008), Peng and Khoury (2009), and Peng, Sun, Pinkham, and Chen

35 (2009). Peng (2005) was more personal, outlining my own journey as an emerging scholar whose research interest grew from an initial focus on

37 China strategy to a more global strategy. Peng et al. (2008) dealt with an institution-based view of IB strategy, with a particular emphasis on emer-

39 ging economies. Peng and Khoury (2009) articulated the two propositions underpinning the institution-based view. Finally, Peng et al. (2009) 
1 proposed that the institution-based view had emerged as a third leg for a strategy tripod - the other two legs being the industry-based and resourcebased views. $^{2}$

While these earlier review papers described the origins and emergence of

5 the institution-based view up to the mid-2000s, what are the new developments of this view in the last decade - especially since these review papers

7 were written? This paper highlights new directions in the deepening and broadening of the institution-based view, drawing on three streams of

9 research with which I have been personally involved in the last 10 years or so. They are: (1) outward foreign direct investment (OFDI) from emerging

11 economies, (2) bankruptcy laws and entrepreneurship development, and (3) institution-based research focusing on Africa. Deepening has been

13 accomplished by enhancing our institution-based understanding of OFDI with a focus on emerging multinationals while broadening has been done

15 both substantively by probing into the impact of bankruptcy laws on entrepreneurship development around the world and geographically by calling

17 for enhanced research attention on Africa via an institution-based lens.

Why are these topics important to IB researchers? In short, they help

19 advanced the institution-based view beyond the widely accepted claim that "institutions matter," by demonstrating how institutions matter in a variety

21 of contexts. Specifically, research on OFDI from emerging economies has become one of the leading topics in IB research. Until recently, existing

23 research on OFDI had focused on established multinationals and not on emerging multinationals so that the new thrust on emerging multinationals

25 thus deepens our knowledge of FDI. Research on Africa is gaining importance because of the dearth of such research and the inclusion of South

27 Africa as one of the BRICS countries. Research on bankruptcy laws and entrepreneurship development is not as popular as the other two streams,

29 but it presents a great opportunity to broaden institution-based research.

35 A casual scan of the recent tables of contents in IB journals leads to the observation that OFDI from emerging economies has become a major

37 research topic because of its novelty in the global economy since the last decade (Hoskisson et al., 2013). However, none of the papers in the two

39 influential special issues on strategy in emerging economies in the Academy of Management Journal (edited by Hoskisson, Eden, Lau, \& Wright, 2000) 
1 and in the Journal of Management Studies (edited by Wright, Filatotchev, Hoskisson, \& Peng, 2005) dealt with this topic. Yet, as multinational enter-

3 prises (MNEs) from emerging economies now generate approximately 20 percent of OFDI globally (Peng, 2014, p. 6), IB scholars have naturally

5 endeavored to shed light on this new phenomenon.

Two fundamental research questions have emerged: (1) can existing the-

7 ories on MNEs and FDI account for this new breed of multinationals and (2) do we need to develop new theories to better capture this new phenom-

9 enon (Cuervo-Cazurra, 2012; Dunning, 2006; Hoskisson et al., 2013; Luo \& Tung, 2007; Mathews, 2006; Peng, 2012; Ramamurti, 2012)? While

11 sizable components of the strategy and behavior of multinationals from emerging economies are consistent with what we observe of MNEs from

13 developed economies, the arrival of emerging multinationals on the global scene has revealed a series of relatively unique aspects (Peng, 2012). Chief

15 among these relatively unique aspects are institution-based differences in OFDI motivation and behavior.

17 Given the liability of foreignness, ${ }^{3}$ why do firms go through the trouble of undertaking FDI and then become MNEs? Guided by Dunning's

19 ownership-location-internalization (OLI) paradigm, existing IB textbooks typically categorize firms' motivations as: (1) natural resource seek-

21 ing, (2) market seeking, (3) efficiency seeking, and/or (4) innovation seeking (Peng, 2014, p. 315). Can these categories help us make sense of the follow-

23 ing empirical anomalies? The number one destination countries of OFDI from Brazil, Russia, and India (the BRI from BRIC) are neither the

25 United States nor the leading countries in Western Europe. Yet, these countries are typically nominated by my own students in different IB

27 classes ranging from undergraduate to EMBA levels when I asked them in class. These students have evidently been strongly influenced by traditional

29 theories such as OLI, thinking that emerging multinationals must be seeking natural resources, markets, efficiency, and/or innovation in their

31 OFDI destination countries. Of course, to some extent such motivations do exist among some emerging MNEs (Yamakawa, Khavul, Peng, \& 33 Deeds, 2013).

However, the largest recipient countries of OFDI from emerging econo-

35 mies are not my students' "usual suspects." Instead, the number one recipient countries of OFDI from Brazil, Russia, and India are the British Virgin

37 Islands (BVI), Cyprus, and Mauritius, respectively. The number one and two recipient economies of OFDI from China are Hong Kong and the

39 BVI. If we consider Hong Kong to be "Chinese," then the number one real foreign country receiving China's OFDI is the BVI (Peng, Sun, \& Blevins, 
1 2011). Likewise, for inward FDI (IFDI) into BRI, the number one originating countries are the BVI, Cyprus, and Mauritius, respectively. For IFDI

3 into China, the top two sources are Hong Kong and the BVI - the number one real foreign source being the BVI (Peng et al., 2011).

5 Is such OFDI natural resource seeking, market seeking, efficiency seeking, or innovation seeking? The answer is most likely no. Since these OFDI

7 recipient countries and IFDI originating countries are widely known as tax havens, a plausible hypothesis is that a significant amount of capital round-

9 tripping comes out of - and then goes back into - emerging economies (Peng, 2012, p. 98). ${ }^{4}$ Why do firms from emerging economies engage in

11 such arduous capital round-tripping? In my view, this must be due to the institution-based weaknesses of their domestic economies that do not offer

13 sufficient protection and incentive for indigenous firms (Peng \& Parente, 2012).

15 Interestingly (or oddly), the home country governments of emerging multinationals often offer strong protection and more preferential treatments

17 for foreign firms (Huang, 2003). ${ }^{5}$ Given such somewhat distorted or "weird" rules of the game, numerous domestic firms in emerging economies have

19 converted themselves to "foreign-owned MNEs" (often registered in the BVI, Cyprus, Hong Kong, and Mauritius) and then managed to come

21 back via capital round-tripping (Fung, Yau, \& Zhang, 2011). In other words, after investing and registering in places such as the BVI, Cyprus,

23 Hong Kong, and Mauritius, a lot of firms that have originated from BRIC now transform their operations in BRIC (their original home countries) as

25 subsidiaries of foreign-owned firms that are registered and headquartered elsewhere.

27 By definition, tax havens help reduce taxes. Of course, the label "tax havens" had been coined a long time ago before emerging multinationals

29 became a force to be reckoned with globally. Since numerous multinationals from developed economies have used tax havens, a fair question is:

31 If governments in emerging economies are creating distortion that leads to capital flight to tax havens such as the BVI, how different is it from the

33 loopholes in the U.S. tax laws that lead to so many special-purpose entities created by U.S. multinationals? ${ }^{6}$ The answer "boils down to the magnitude

35 of degree" (Peng, 2012, p. 103). Despite the numerous U.S. special-purpose entities in the BVI (presumably for tax purposes), the BVI appears neither

37 among the top five recipient countries of OFDI from the United States nor among the top five countries making IFDI in the United States. ${ }^{7}$ In con-

39 trast, the BVI is routinely among the top three for both OFDI from China and IFDI into China (Peng, 2012, p. 103). Likewise, the BVI is routinely 
1 the number one country for both OFDI from Brazil and IFDI into Brazil (Peng \& Parente, 2012, p. 362). Clearly, something not captured by tradi-

3 tional FDI theories is going on.

Despite the differences in the use of tax havens between developed5 economy and emerging-economy multinationals, I argue that, beyond simple tax administration, emerging multinationals also engage in institutional

7 arbitrage when undertaking OFDI in tax havens (Hoskisson et al., 2013; Peng \& Su, 2014). These firms may use these offshore locations' corporate

9 laws, which are generally influenced by higher quality English common law, to improve their own corporate governance and initiate restructuring

11 at home (Vlcek, 2013, p. 13). Specifically, such BRIC-originated firms may introduce Western corporate governance mechanisms, appoint Western

13 talent to the board and top management team, and initiate sometimes tough restructuring at home, citing the necessity to follow "international"

15 norms. Their room for such maneuvers would probably have been limited had they stayed purely domestic within the BRIC group and other emer-

17 ging economies.

Commenting on how to make theoretical progress dealing with OFDI

19 from emerging economies, I have suggested that "at this point, it is neither clear whether existing theories can adequately account for this new phe-

21 nomenon, nor evident that we need entirely new theories" (Peng, 2012, p. 105). However, to supplement OLI-based existing FDI theories, I do

23 believe that, in the future, there is scope to develop an institution-based theory of FDI that can go above and beyond the insights provided by tra-

25 ditional theories. Since FDI is one of the most enduring topics in IB, the new research on OFDI from emerging economies serves to deepen the long-

27 established stream in IB research. Now that we have shown how the institution-based view can deepen IB research, we turn to the separate

29 issues of how this view can broaden IB research by venturing to previously underexplored areas.

BANKRUPTCY LAWS AND ENTREPRENEURSHIP DEVELOPMENT

37 Tracing its roots to Schumpeter (1942), an institution-based view of entrepreneurship seeks to understand how institutions matter for it (Bruton,

39 Ahlstrom, \& Li, 2010; Zhu, Wittmann, \& Peng, 2012). My recent research has focused on three cumulative articles progressing from theory building 
1 (Lee, Peng, \& Barney, 2007) to qualitative investigation (Peng, Yamakawa, \& Lee, 2010), and finally to quantitative hypothesis testing (Lee, Yamakawa,

3 Peng, \& Barney, 2011). Inspired by the challenge to demonstrate how institutions matter, these efforts have been dedicated to answering a

5 specific question: if bankruptcy laws can be viewed as a case of formal institutions governing entrepreneurship, how do bankruptcy laws affect entrepre-

7 neurship development around the world?

My motivation stemmed from my dissatisfaction with the "anti-failure"

9 bias in much of the scholarly literature and popular press about entrepreneurship (Lee et al., 2007). This bias can be found by the overwhelming

11 interest in entrepreneurial success and the very limited interest in entrepreneurial failure (Yamakawa, Peng, \& Deeds, 2014). Although a majority of

13 entrepreneurs fail, the scholarly and popular literature tends to lionize the few shining examples of success and essentially urge a new generation to

15 learn from the successful entrepreneurs' highly idiosyncratic and lucky! experiences. Given that most self-respecting governments encourage more

17 individuals to launch entrepreneurial start-ups and that most such start-ups fail, how can government policies as "rules of the game" facilitate more 19 entrepreneurship development?

From an institution-based view, we argue that societies that are friend-

21 lier and more forgiving to failed entrepreneurs are likely to attract more individuals to start up new ventures and to benefit from the strong eco-

23 nomic development that comes with vibrant entrepreneurial activities (Lee et al., 2007, 2011). Conversely, "societies that are harsher to failed entrepre-

25 neurs whose start-ups end up in bankruptcy will discourage entrepreneurship development" (Peng et al., 2010, p. 518). For example, in Germany,

27 until the recent bankruptcy law reforms, the debtor would remain liable for unpaid debt for up to 30 years (Peng et al., 2010, p. 523). In South Korea,

29 bankrupt entrepreneurs and managers are almost always fired and replaced (Peng et al., 2010, pp. 524-525). In part, due to such harsh treatment

31 of bankrupt individuals, entrepreneurship development in Germany and South Korea (as measured by new firm entries) is often less than ideal.

33 Historically, entrepreneur friendliness and bankruptcy laws seem to be an "oxymoron" because bankruptcy laws are usually harsh and even cruel.

35 The very term "bankruptcy" is derived from a harsh practice in medieval Italy where, if bankrupt entrepreneurs did not pay their debt, debtors

37 would destroy the trading booth of the bankrupt person. The Italian word for broken booth, "banca rotta," did evolve to become the English

39 word "bankruptcy." The pound of flesh demanded by the creditor in Shakespeare's The Merchant of Venice is only a slight exaggeration. The 
1 world's first bankruptcy law, passed in England in 1542, considered a bankrupt individual a criminal, and punishments ranged from incarceration in

3 prison to the death sentence (Peng et al., 2010, p. 518).

Around the world, being entrepreneur friendly is a relatively new con-

5 cept in radical contrast with traditional bankruptcy laws that generally favored the creditor and were harsh toward the bankrupt debtor (Halliday

7 \& Carruthers, 2007). Recently, many governments around the world have increasingly realized that entrepreneur-friendly bankruptcy laws can not

9 only lower exit barriers but also lower entry barriers for entrepreneurs (Peng et al., 2010, p. 522).

11 Bankruptcy laws traditionally focus on liquidation by dismembering the firm and selling its assets to repay creditors - in the same spirit of breaking

13 bankrupt merchants' trading booth in medieval Italy. More entrepreneurfriendly bankruptcy laws in some countries allow for a second option:

15 namely, reorganization that gives a firm certain legal protection while it sheds some debt and reorganizes in order to compete more effectively.

17 Known as Chapter 11 in the United States, such reorganization enables some firms, which are in temporary financial distress, to eventually become

19 successful. However, not all countries have reorganization as a bankruptcy option. For instance, bankruptcy laws in Finland do not include this

21 option, and bankrupt Finnish entrepreneurial firms are thus forced to liquidate immediately. Clearly, providing an opportunity for bankrupt firms to

23 reorganize is more entrepreneur friendly than forcing them to liquidate.

In the United States, the Bankruptcy Act of 1898 was the first to give

25 firms in distress some protection from creditors. The widely used Chapter 11 reorganization was enacted by the Bankruptcy Reform Act of

271978 that took effect in 1979. The post-1979 entrepreneurship development in the United States has been enviable. That is why there is a recent global

29 trend to add the U.S. Chapter 11-type reorganization bankruptcy as one of the choices for bankrupt firms in countries such as Argentina, Australia,

31 Britain, China, Indonesia, South Korea, and Thailand (Halliday \& Carruthers, 2007).

33 Beyond such qualitative evidence, our detailed quantitative work with a cross-country database from 29 countries spanning 19 years (1990-2008)

35 endeavored to link the specific provisions of bankruptcy laws with the rates of new firm formation - the ratio of the number of new firms to the total

37 number of firms in a country (Lee et al., 2011, p. 511). For example, the time spent on bankruptcy procedures can make a difference because, in a

39 liquidation bankruptcy, a fast procedure allows the quick reallocation of assets of failed firms to better uses. At the same time, a fast procedure can 
1 provide entrepreneurs some opportunities to start up new businesses. Lee et al. (2011, p. 515) showed that 0.03 years (approximately 10 days)

3 spent on bankruptcy procedures compared to 2.36 years is associated with a 10 percent increase in the likelihood of a new firm entry. The difference

5 between 1.04 and 12.93 percent of an estate spent on closing costs translates into more than an 11 percent higher likelihood of new firm entry.

7 Overall, making bankruptcy laws more friendly, helpful, and forgiving to entrepreneurs whose firms are bankrupt will positively affect entrepre-

9 neurship development by lowering both exit barriers and entry barriers. ${ }^{8}$ Similar to the saying "No pain, no gain," an economy unwilling to

11 shoulder the costs of certain entrepreneurial failures is not likely to reap the benefits of a strong entrepreneurial sector and the economic growth it

13 may bring (Yamakawa et al., 2013). From an institution-based view, we advocate more entrepreneur-friendly bankruptcy laws designed to make the

15 "pain" less painful for failed entrepreneurs and their firms, and to "gain" from more vibrant entrepreneurship development.

\section{INSTITUTION-BASED RESEARCH} FOCUSING ON AFRICA

23 Given the paucity of research interest and output, Africa remains the "final frontier" in our research (Zoogah, Peng, \& Woldu, 2013). ${ }^{9}$ One of the core

25 propositions of the institution-based view is that managers and firms rationally pursue their interests and make choices within a given institu-

27 tional framework (Peng \& Khoury, 2009, p. 260; Peng et al., 2009, p. 67). ${ }^{10}$ Developed primarily in Western economies, most theories model firms and

29 markets independently of institutional contexts. Such theories typically assume the existence of a market-based framework while such important

31 institutional factors as the existence of formal legal and regulatory frameworks have often been taken for granted and assumed away as "back-

33 ground." In contrast, researchers working on emerging economies in Asia and Central and Eastern Europe have noted the importance of institutions

35 in shaping management behavior and the hazard of failing to appreciate institutional forces (Boddewyn \& Doh, 2011; Khanna \& Yafeh, 2007;

37 Meyer \& Peng, 2005; Peng et al., 2008). Given the more radical contrast between the institutional frameworks in Africa and those in developed

39 economies (Fafchamps, 2004; Kamoche \& Harvey, 2006), I believe that the institution-based view will be especially insightful for Africa research and 
1 will also gain significant new theoretical mileage there. Chief among the institution-based differences between African and the rest of the world

3 are: (1) manufacturing versus agricultural rules of the game, (2) formal versus informal land rights, and (3) formal versus informal contract 5 enforcement.

Most modern (Western) theories of management and organization 7 emerged out of a manufacturing setting with its own "rules of the game." These "taken-for-granted" rules include individuals" interest in wage work,

9 familiarity with formal organizational rules, and propensity to use formal contracts. However, manufacturing is a relatively young sector in Africa

11 where it is "largely a creation of the past 50 years" (Collier \& Gunning, 1999, p. 76). Much of the African workforce (approximately 80 percent) is

13 in agriculture (World Bank, 2007). How formal institutions and informal norms govern agriculture has significant ramifications not only for agricul-

15 ture but also for the manufacturing and service industries that typically absorb labor forces which have had experience in agriculture.

17 In many African countries, a traditional system of land rights (which emphasizes informal, customary, and communal ownership rights that do

19 not grant exclusive use) is being transformed into a more modern system that focuses on formal and individual rights (which often grant exclusive

21 use). Only approximately one percent of land in Africa is formally registered with governments (Easterly, 2008, p. 97). Thus, the institutional tran-

23 sitions are essentially a movement from informal property rights to formal property rights that are supported by government authorities with third-

25 party enforcement powers (Decker, 2010; Peng, 2003). While research on Asia has often noted that the Asian propensity to use informal interperso-

27 nal relationships to get things done is largely due to a lack of an effective formal property rights system (Peng \& Luo, 2000; Puffer, McCarthy, \&

29 Peng, 2013), it is plausible to suggest that, relative to Asians, Africans may have a higher propensity to rely on informal interpersonal relationships

31 because of their agricultural environment featuring informal land titles and property rights, in which most of them have some experience (Acquaah, 33 2007).

What types of informal interpersonal relationships are more helpful

35 to managers? Acquaah (2007) found that social capital possessed and nurtured by managers in their dealings with (1) managers in other firms,

37 (2) government officials, and (3) community leaders (such as chiefs and elders) directly contribute to firm performance. Conducted in Ghana,

39 Acquaah's (2007) study replicated and extended Peng and Luo's (2000) research in China - the first study in an emerging economy replicating an 
1 earlier work in another emerging economy whereas most replications in Africa and other emerging economies have benchmarked themselves

3 against the West. While Acquaah (2007) largely supported the Chinese findings, he reported an important finding different from that of Peng and

5 Luo (2000) - namely, that ties with government officials in Ghana (although statistically significant) were not as important as those ties in

7 China. In an interesting extension, Acquaah (2007) reported that ties with community leaders such as chiefs and elders - a unique African insti-

9 tution - have a more significant impact on firm performance. ${ }^{11}$ Overall, Acquaah's (2007) findings represent a major contribution to the institution-

11 based view by leveraging the African context.

Institution-based research on institutional transitions in Asia and

13 Central and Eastern Europe has largely focused on the transitions toward more formal institutions in governing market exchange and in facilitating

15 economic growth (Ismail, Ford, Wu, \& Peng, 2013; Meyer \& Peng, 2005; Peng, 2003; Zhou \& Peng, 2010). However, theoretically, formal institu-

17 tions are not necessarily better or more efficient in governing market exchange because, in many situations, the demand for formal institutions

19 may not be evident (Ostrom, 1990, p. 216). In other words, formal institutions may not necessarily be better or more efficient in governing market

21 exchange in some cases, due to their inconsistency with ingrained informal institutions and to the inability of governments to make credible commit-

23 ments (Ostrom, 1990).

The struggles associated with formal property rights in Africa represent

25 an ideal context in which to test this institution-based claim. Although there is some evidence that formal land titles promote more investment by

27 farmers, other evidence indicates that formal land titling, which often overrides traditional rights, is ineffective in facilitating more investment

29 and growth in agriculture (Collier \& Gunning, 1999, p. 79). This is because formal land titling "can increase, rather than decrease, uncer31 tainty about who has what rights to the land" (Easterly, 2008, p. 97). For example, communal land ownership often results in "swapping plots

33 between kin and seasonal exchanges of land for labor and livestock" (Easterly, 2008, p. 97). Each household often has "use rights" but not 35 necessarily "ownership rights" to many plots, and disputes are often resolved informally - for example, through community leaders such as

37 chiefs and elders (Acquaah, 2007; Khavul, Bruton, \& Wood, 2009). ${ }^{12}$ Not surprisingly, formally assigning one plot to a single household, thereby

39 excluding the "use rights" of other households, creates uncertainty, tension, and conflicts. 
1 A primary role of institutions - both formal and informal, modern and traditional - is to reduce uncertainty (North, 1990; Peng et al., 2009). In

3 the absence of formal institutions such as effective legal frameworks for land titles, the enforcement of commercial contracts becomes very 5 informal - a tendency that applies to both rural and urban settings in Africa (Fafchamps, 1996). Hence, cultivating good interpersonal relation-

7 ships with those representing authorities (such as chiefs and elders in rural settings and government officials in urban settings) becomes a coping strat-

9 egy to combat uncertainty. For creditors without such informal but highly useful connections, "harassment is the main form of debt collection"

11 (Fafchamps, 1996, p. 427). My point is not that African countries do not have formal courts and other legal mechanisms because, in fact, they have

13 such formal institutions. However, these formal institutions are seldom used because the cost involved often outweigh the value of using them

15 (Peng, 2003). Hence, informal arbitration often becomes a default option in alleviating uncertainty and resolving disputes. ${ }^{13}$

17 The strategic implications of such an institutional framework for African firms are twofold. First, managers and firms need to invest time

19 and money to cultivate important relationships (Khavul et al., 2009). Second, firms are forced to informally do business with a small number of

21 known entities, with whom some level of trust can be built. Given the institutional conditions, this is a perfectly rational strategy (Peng et al., 2009)

23 and return on capital in the informal sector can be "quite high" (Udry \& Anagol, 2006, p. 392). ${ }^{14}$ The upshot is that most transactions in Africa are

25 informal and local in nature, and they follow a "flea market" mode of "cash and carry." Approximately 72 percent of Africa's workforce

27 (Godfrey, 2011, p. 234) and more than 40 percent of Africa's economy (The Economist, 2005, p. 61) are reportedly "informal," with the highest

29 proportions in the world.

Finally, the implications for multinationals interested in doing business

31 in Africa are also clear. Integrating the institution-based and resourcebased views (Ahn \& York, 2011; Meyer et al., 2009), I would argue that

33 foreign firms with the best capabilities to navigate the institutional conditions in Africa will end up being the best-performing ones in such an envir-

35 onment. Consistent with this argument, Cuervo-Cazurra and Genc (2008), using data from 36 least-developed countries (LLDCs) in Africa, reported

37 that the worse the institutions of a particular LLDC host country, the greater the prevalence of MNEs from emerging economies. While MNEs

39 from these economies rarely appear among the largest ones in the world, they are more likely to be among the largest foreign firms active in African less-developed countries. 
These African LLDCs represent a very challenging environment with low gross domestic product and high corruption. Yet, some MNEs

3 from emerging economies are more familiar with such more challenging institutional conditions and have more appropriate and thus more formid-

5 able organizational capabilities for succeeding in such environments (Cuervo-Cazurra \& Genc, 2008). In other words, the firm-specific advan-

7 tages of certain MNEs from emerging economies may enable them to better leverage their home country-specific advantages in the new institutional

9 environment of African LLDCs (Rugman, 2005).

In summary, while institution-based research with a focus on Africa is

11 still in its infancy, it has already made important contributions and holds great promise to further deepening our understanding of the drivers of firm

13 performance in various challenging institutional environments. Instead of being deterred by the more radical contrast between the institutional envir-

15 onment in Africa and that in other parts of the world, I argue that such contrast represents a golden opportunity to broaden the institution-based

17 view (Zoogah et al., 2013).

\section{CONCLUSION}

23 There is hardly any controversy on the claim that "institutions matter." A new generation of institution-based research needs to uncover how insti25 tutions matter. This paper contributes to the literature by using three research streams with which I have been personally involved recently to

27 demonstrate how institutions matter in a variety of contexts. Looking forward, I believe that further research on OFDI from emerging economies

29 has potential to develop a theory of institution-based weaknesses behind such OFDI (Hoskisson et al., 2013; Peng, 2012; Peng \& Parente, 2012).

31 Additional research on bankruptcy laws can have major public policy implications in terms of making bankruptcy laws more entrepreneur

33 friendly in order to facilitate more entrepreneurship development around the world (Lee et al., 2007, 2011; Peng et al., 2010). ${ }^{15}$ Finally, Africa holds

35 a key to unlocking the potential insights of the institution-based view in a highly dynamic but largely underexplored context (Zoogah et al., 2013).

37 While institutions matter, emerging institution-based research focusing on Africa suggests that "developed institutions" are not necessarily always a

39 plus. There can be weaknesses associated with certain "developed institutions" such as formal land titles. Overall, while the selection of these three areas is driven by my own idiosyncratic personal research interests, I hope 
1 that they can help readers appreciate the increasing depth and expanding breadth of recent research based on the institution-based view.

Of course, new developments in the institution-based view can be found along many other dimensions not covered in this paper. As a family of theories, the institution-based view has now given birth to an institution-based view of corporate governance (Globerman, Peng, \& Shapiro, 2011; Jiang \&

7 Peng, 2011; Lu, Au, Peng, \& Xu, 2013; Peng \& Jiang, 2010; Sauerwald \& Peng, 2013; Van Essen, Huegens, Otten, \& van Oosterhout, 2012; Young,

9 Peng, Ahlstrom, Bruton, \& Jiang, 2008), an institution-based view of corporate diversification (Kim et al., 2010; Lee, Peng, \& Lee, 2008; Peng, Lee,

11 \& Wang, 2005), an institution-based view of mergers and acquisitions (Lin, Peng, Yang, \& Sun, 2009; Yang, Sun, Lin, \& Peng, 2011), and an

13 institution-based view of knowledge management and intellectual property rights (Khoury \& Peng, 2011; Lu et al., 2008; Mahlich, 2010; Peng, 2013).

15 Clearly, the institution-based view has been significantly deepened and broadened recently.

17 While it has long been known that the rules of the game that specify the relative pay-offs play a key role in determining individual and organiza-

19 tional behaviors, we have just set out on the long road to achieving a solid understanding of how institutions matter along a variety of dimensions in

21 which IB scholars are interested. In addition to conducting research to inform the scholarly community, institution-based scholars need to aspire

23 to disseminate our learning via textbook writing (Peng, 2014; Stambaugh \& Trank, 2010) and public policy engagements (Peng \& Meyer, 2013; Peng

25 et al., 2011). In conclusion, if this paper can contain one message, I would like it to be a sense of the excitement associated with the future develop27 ment of the institution-based view around the world.

\section{NOTES}

1. According to Alan Rugman (2013, p. 3), Chair of the first Buckley and 33 Casson AIB Best Dissertation Award Committee, of the 22 dissertations submitted for the competition in 2013, 15 used the institution-based view.

35 2. Examples of recent research that has leveraged and extended the strategy tripod include Gao, Murray, Kotabe, and Lu (2010), Krull, Smith, and Ge (2012), Lu, Liu, and Wang (2011), Xie, Zhao, Xie, and Arnold (2011), and Yamakawa, Peng, and Deeds (2008).

3. While IB scholars are generally familiar with the notion of the liability of 39 foreignness, there is some research that shows that foreignness can be an asset 
1 (Brannen, 2004). This is because sometimes being foreign enhances the prestige and thus the marketability of certain products and services in some overseas markets.

4. Capital round-tripping refers to the phenomenon of firms from country A invest in country B, and then reinvest back in country A (Fung et al., 2011).

5. This is not to say that foreign firms always enjoy the upper hand in emerging economies. They sometimes complain about "unfair" treatment as well (Peng, 2014).

6. A special-purpose entity is a legal entity (usually a limited company of some type or, sometimes, a limited partnership) created to fulfill narrow, specific, or temporary objectives.

7. The United States and other industrialized countries have been clamping down on some of these tax-evasion strategies of multinationals.

11 8. Of course, bankruptcy laws are not the only factor that affects entrepreneurship development. Other institution-based factors as well as numerous noninstitution-based factors play a role in entrepreneurship development. However, our institution-based perspective centered on the entrepreneur friendliness of bankruptcy laws is often overlooked in discussions on how to promote entrepreneurship

15 development, thus necessitating our attention.

9. Zoogah et al. (2013) investigated all Africa-focused studies in 26 leading 17 management journals (including all leading IB journals) during the last five decades (1960-2011). They found a total of 152 articles - an embarrassing 2.92 articles per year for the entire field. In IB's leading outlet the Journal of International Business

19 Studies, only two Africa-focused articles were published during such a long time.

10. In theoretical terms, "the rationality discussed here is bounded (but not per-

21 fect) rationality" (Peng et al., 2009, p. 67). Specifically, managers and firms are assumed to be "intendedly rational, but only limitedly so" (Simon, 1961, p. xxiv).

11. While the role of elders and chiefs in Africa is important, there is insufficient research - in IB and management at least - to assess how the role of elders and chiefs in tribal societies differs from that of nontribal leaders in other societies. This remains an interesting direction for future research.

12. Such informal and communal use rights are different from public ownership under communism, which is more formal with a higher degree of bureaucratization.

13. It is true that in some industrialized countries such as Japan, formal courts are not used as often either. Therefore, it is questionable whether the African tendency to bypass formal courts is unique. I thank a reviewer for raising this thoughtprovoking point. While I can speculate about the institution-based rationale behind

31 the Japanese hesitation to use formal courts, I think it is more honest to confess my ignorance, in the absence of any literature comparing African and Japanese conflictresolution styles.

14. Using data from Ghana, Udry and Anagol (2006, p. 389) found that return on investment in pineapple cultivation in the informal sector is "extremely high," in the $250-300$ percent range.

15. In 2008, a conference version of Lee et al. (2011) received a U.S. Small

37 Business Administration Award for the Best Babson Conference Paper "exploring the importance of small businesses to the U.S. economy or a public policy issue of importance to the entrepreneurial community" (award citation), with a press release posted at www.sba.gov/advo/press/08-14.html. 
3 I greatly appreciate Jean J. Boddewyn's support and encouragement. Thanks are also due to Alan Rugman and Rosalie Tung for constructive

5 feedback, and to Steve Sauerwald and Cristina Vlas for research assistance. I also acknowledge support from the Jindal Chair at UT Dallas.

7 I remain grateful to John Dunning's tremendous support. Despite his busy schedule and declining health, he accepted my invitations twice to

9 contribute to the Asia Pacific Journal of Management, when I served as its Editor-in-Chief. Dunning's (2006) piece is a commentary on Mathews

11 (2006), which has gone on to become an influential article in the literature on emerging multinationals. As indicated by the title, Dunning and

13 Lundan (2008) dealt with "institutions and the OLI paradigm of the multinational enterprise." It turned out to be the last article concluding

15 Dunning's illustrious career before his death in 2009.

\section{REFERENCES}

Acquaah, M. (2007). Managerial social capital, strategic orientation, and organizational performance in an emerging economy. Strategic Management Journal, 28, 1235-1255.

Ahn, M. J., \& York, A. S. (2011). Resource-based and institution-based approaches to biotechnology industry development in Malaysia. Asia Pacific Journal of Management, $28,257-275$.

Ahuja, G., \& Yayavaram, S. (2011). Explaining influence rents: The case for an institutionbased view of strategy. Organization Science, 22, 1631-1652.

Boddewyn, J., \& Doh, J. (2011). Global strategy and the collaboration of MNEs, NGOs, and governments for the provisioning of collective goods in emerging markets. Global Strategy Journal, 1, 345-361.

29 Brannen, M. Y. (2004). When Mickey loses face: Recontextualization, semantic fit, and the semiotics of foreignness. Academy of Management Review, 29, 593-616.

Bruton, G. D., Ahlstrom, D., \& Li, H. (2010). Institutional theory and entrepreneurship: Where are we now and where do we need to move in the future? Entrepreneurship Theory and Practice, 34, 421-440.

33 Carney, M., Gedajlovic, E., \& Yang, X. (2009). Varieties of Asian capitalism: Toward an institutional theory of Asian enterprise. Asia Pacific Journal of Management, 26, 361-380.

Chari, M. D. R., \& David, P. (2012). Sustaining supplier performance in an emerging economy: An empirical test in the Indian context. Strategic Management Journal, 33, $217-229$.

Collier, P., \& Gunning, J. W. (1999). Explaining African economic performance. Journal of Economic Literature, 37, 64-111.

39 Cuervo-Cazurra, A. (2012). Extending theory by analyzing developing country multinational companies: Solving the Goldilocks debate. Global Strategy Journal, 2, 153-167. 
1 Cuervo-Cazurra, A., \& Genc, M. (2008). Transforming disadvantages into advantages: Developing-country MNEs in the least developed countries. Journal of International Business Studies, 39, 957-979.

Dau, L. A. (2012). Pro-market reforms and developing country multinational corporations. Global Strategy Journal, 2, 262-276.

Decker, S. (2010). Postcolonial transitions in Africa: Decolonization in West Africa and present day South Africa. Journal of Management Studies, 47, 791-813.

Dunning, J. H. (2004). An evolving paradigm of the economic determination of international business activity. In J. Cheng \& M. A. Hitt (Eds.), Managing multinationals in a knowledge economy (pp. 3-27). Oxford: Elsevier.

Dunning, J. H. (2006). Comment on "Dragon multinationals: New players in 21st century globalization". Asia Pacific Journal of Management, 23(2), 139-141.

11 Dunning, J. H., \& Lundan, S. M. (2008). Institutions and the OLI paradigm of the multinational enterprise. Asia Pacific Journal of Management, 25(4), 573-594.

Easterly, W. (2008). Institutions: Top down or bottom up? American Economic Review, 98, 95-99.

Fafchamps, M. (1996). The enforcement of commercial contracts in Ghana. World Development, 24, 427-448.

Fafchamps, M. (2004). Market institutions in Sub-Saharan Africa. Cambridge, MA: MIT Press.

Fung, H.-G., Yau, J., \& Zhang, G. (2011). Reported trade figure discrepancy, regulatory arbitrage, and round-tripping: Evidence from the China-Hong Kong trade data. Journal of International Business Studies, 42, 152-176.

Gao, G. Y., Murray, J. Y., Kotabe, M., \& Lu, J. (2010). A strategy tripod perspective on export behavior: Evidence from domestic and foreign firms based in an emerging economy. Journal of International Business Studies, 41, 377-396.

Globerman, S., Peng, M. W., \& Shapiro, D. M. (2011). Corporate governance and Asian companies. Asia Pacific Journal of Management, 28(1), 1-14.

Godfrey, P. C. (2011). Toward a theory of the informal economy. Academy of Management Annals, 5(1), 231-277.

Halliday, T. C., \& Carruthers, B. G. (2007). The recursivity of law: Global norm making and national lawmaking in the globalization of corporate insolvency regimes. American Journal of Sociology, 112, 1135-1202.

Hoskisson, R. E., Eden, L., Lau, C.-M., \& Wright, M. (2000). Strategy in emerging economies. Academy of Management Journal, 43, 249-267.

Hoskisson, R. E., Wright, M., Filatotchev, I., \& Peng, M. W. (2013). Emerging multinationals from mid-range economies: The influence of institutions and factor markets. Journal of Management Studies, 50(7), 1295-1321.

Huang, Y. (2003). Selling China. New York, NY: Cambridge University Press.

Ismail, K. M., Ford, D. L., Wu, Q., \& Peng, M. W. (2013). Managerial ties, strategic initiatives, and firm performance in Central Asia and the Caucasus. Asia Pacific Journal of Management, 30(2), 433-446.

Jiang, Y., \& Peng, M. W. (2011). Are family ownership and control in large firms good, bad, or irrelevant? Asia Pacific Journal of Management, 28(1), 15-39.

Kamoche, K., \& Harvey, M. (2006). Knowledge diffusion in the African context: An institutional theory perspective. Thunderbird International Business Review, 48, 157-181.

Khanna, T., \& Yafeh, Y. (2007). Business groups in emerging markets: Paragons or parasites? Journal of Economic Literature, 45, 331-372. 
1 Khavul, S., Bruton, G. D., \& Wood, E. (2009). Informal family business in Africa. Entrepreneurship Theory and Practice, 33, 1219-1238.

Khoury, T. A., \& Peng, M. W. (2011). Does institutional reform of intellectual property rights lead to more FDI? Evidence from Latin America and the Caribbean. Journal of World Business, 46, 337-345.

5 Kim, H., Kim, H., \& Hoskisson, R. E. (2010). Does market-oriented institutional change in an emerging economy make business group-affiliated multinationals perform better? An institution-based view. Journal of International Business Studies, 41, 1141-1160.

Krull, E., Smith, P., \& Ge, G. L. (2012). The internationalization of engineering consulting from a strategy tripod perspective. Service Industries Journal, 32, 1097-1119.

Lee, K. B., Peng, M. W., \& Lee, K. (2008). From diversification premium to diversification discount during institutional transitions. Journal of World Business, 43(1), 47-65.

11 Lee, S.-H., Peng, M. W., \& Barney, J. B. (2007). Bankruptcy law and entrepreneurship development: A real options perspective. Academy of Management Review, 32(1), $257-272$.

Lee, S.-H., Yamakawa, Y., Peng, M. W., \& Barney, J. B. (2011). How do bankruptcy laws affect entrepreneurship development around the world? Journal of Business Venturing, 26, 505-520.

Lin, Z., Peng, M. W., Yang, H., \& Sun, S. L. (2009). How do networks and learning drive M\&As? An institutional comparison between China and America. Strategic Management Journal, 30, 1113-1132.

Liu, W., Yang, H., \& Zhang, G. (2012). Does family business excel in firm performance? An institution-based view. Asia Pacific Journal of Management, 29, 965-987.

Lu, J., Liu, X., \& Wang, H. (2011). Motives for outward FDI of Chinese private firms: Firm resources, industry dynamics, and government policies. Management and Organization Review, 7, 223-248.

Lu, Y., Au, K., Peng, M. W., \& Xu, E. (2013). Strategic management in private and family businesses. Asia Pacific Journal of Management, 30(3), 633-639.

Lu, Y., Tsang, E. W. K., \& Peng, M. W. (2008). Knowledge management and innovation strategy in the Asia Pacific: Toward an institution-based view. Asia Pacific Journal of Management, 25(3), 361-374.

Luo, Y., \& Tung, R. L. (2007). International expansion of emerging market enterprises: A springboard perspective. Journal of International Business Studies, 38, 481-498.

Mahlich, J. (2010). Patents and performance in the Japanese pharmaceutical industry: An institution-based view. Asia Pacific Journal of Management, 27, 99-113.

Mathews, J. A. (2006). Dragon multinationals: New players in 21 st century globalization. Asia

31 Pacific Journal of Management, 23, 5-27.

Meyer, K. E., Estrin, S., Bhaumik, S., \& Peng, M. W. (2009). Institutions, resources, and entry strategies in emerging economies. Strategic Management Journal, 30(1), 61-80.

Meyer, K. E., \& Peng, M. W. (2005). Probing theoretically into Central and Eastern Europe: Transactions,resources, and institutions. Journal of International Business Studies, 35, $600-621$.

North, D. C. (1990). Institutions, institutional change, and economic performance. Cambridge, MA: Harvard University Press.

Ostrom, E. (1990). Governing the commons: The evolution of institutions for collective action. New York, NY: Cambridge University Press.

Peng, M. W. (2002). Towards an institution-based view of business strategy. Asia Pacific Journal of Management, 19(2-3), 251-267. 
1 Peng, M. W. (2003). Institutional transitions and strategic choices. Academy of Management Review, 28(2), 275-296.

Peng, M. W. (2005). From China strategy to global strategy. Asia Pacific Journal of Management, 22(2), 123-141.

Peng, M. W. (2012). The global strategy of emerging multinationals from China. Global Strategy Journal, 2(2), 97-107.

Peng, M. W. (2013). An institution-based view of IPR protection. Business Horizons, 56(2), $135-139$.

Peng, M. W. (2014). Global business (3rd ed.). Cincinnati, OH: South-Western Thomson.

Peng, M. W., \& Jiang, Y. (2010). Institutions behind family ownership and control in large firms. Journal of Management Studies, 47(2), 253-273.

Peng, M. W., \& Khoury, T. A. (2009). Unbundling the institution-based view of international business strategy. In A. Rugman (Ed.), Oxford handbook of international business (pp. 256-268). Oxford, UK: Oxford University Press.

Peng, M. W., Lee, S.-H., \& Wang, D. (2005). What determines the scope of the firm over time? A focus on institutional relatedness. Academy of Management Review, 30(3), $622-633$.

15 Peng, M. W., \& Luo, Y. (2000). Managerial ties and firm performance in a transition economy: The nature of a micro-macro link. Academy of Management Journal, 43(3), $486-501$.

Peng, M. W., \& Meyer, K. E. (2013). Winning the future markets for UK manufacturing output. The future of manufacturing project evidence paper 25. London: UK Government Office for Science.

Peng, M. W., \& Parente, R. (2012). Institution-based weaknesses behind emerging multinationals. Revista de Administração de Empresas, 52(3), 360-364.

Peng, M. W., \& Su, W. (2014). Cross-listing and the scope of the firm. Journal of World Business, 49(1), 42-50.

Peng, M. W., Sun, S. L., \& Blevins, D. (2011). The social responsibility of international business scholars. Multinational Business Review, 19(2), 106-119.

25 Peng, M. W., Sun, S. L., Pinkham, B., \& Chen, H. (2009). The institution-based view as a third leg for a strategy tripod. Academy of Management Perspectives, 23(3), 63-81.

Peng, M. W., Wang, D., \& Jiang, Y. (2008). An institution-based view of international business strategy: A focus on emerging economies. Journal of International Business Studies, 39(5), 920-936.

Peng, M. W., Yamakawa, Y., \& Lee, S.-H. (2010). Bankruptcy laws and entrepreneurfriendliness. Entrepreneurship Theory and Practice, 34(3), 517-530.

31 Pinkse, J., \& Kolk, A. (2012). Multinational enterprises and climate change: Exploring institutional failures and embeddedness. Journal of International Business Studies, 43, $332-341$.

Puffer, S. M., McCarthy, D., \& Peng, M. W. (2013). Managing favors in a global economy. Asia Pacific Journal of Management, 30(2), 321-326.

35 Ramamurti, R. (2012). What is really different about emerging market multinationals? Global Strategy Journal, 2, 41-47.

Ritchie, W. J., \& Melnyk, S. A. (2011). The impact of emerging institutional norms on adoption timing decisions: Evidence from C-TPAT - a government antiterrorism initiative. Strategic Management Journal, 32, 860-870. 
1 Rugman, A. (2013). From the Richard N. Farmer to the Peter J. Buckley and Mark Casson AIB Dissertation Award. AIB Insights, 13(3), 4-6.

Sauerwald, S., \& Peng, M. W. (2013). Informal institutions, shareholder coalitions, and principal-principal conflicts. Asia Pacific Journal of Management, 30(3), 853-870.

Schumpeter, J. (1942). Capitalism, socialism, and democracy. New York, NY: Harper.

Shinkle, G. A., \& Kriauciunas, A. P. (2012). The impact of current and founding institutions on strength of competitive aspirations in transition economies. Strategic Management Journal, 33, 448-458.

Simon, H. A. (1961). Administrative behavior (2nd ed.). New York, NY: Macmillan.

Stambaugh, J. E., \& Trank, C. Q. (2010). Not so simple: Integrating new research into textbooks. Academy of Management Learning and Education, 9, 663-681.

The Economist. (2005). Doing business in Africa. The Economist, July 2, p. 61.

11 Udry, C., \& Anagol, S. (2006). The return to capital in Ghana. American Economic Review, 96, 388-393.

Van Essen, M., Huegens, P., Otten, J., \& van Oosterhout, J. (2012). An institution-based view of executive compensation: A multilevel meta-analysis. Journal of International Business Studies, 43, 396-423.

15 Vlcek, W. (2013). From road town to Shanghai: Situating the Caribbean in global capital flows to China. British Journal of Politics and International Relations.

17 World Bank. (2007). World development report 2008. Washington, DC: World Bank.

Wright, M., Filatotchev, I., Hoskisson, R. E., \& Peng, M. W. (2005). Strategy research in emerging economies: Challenging the conventional wisdom. Journal of Management Studies, 42(1), 1-33.

Xie, Y. H., Zhao, H. J., Xie, Q. J., \& Arnold, M. (2011). On the determinants of post-entry strategic positioning of foreign firms in a host market: A strategy tripod perspective. International Business Review, 20, 477-490.

Yamakawa, Y., Khavul, S., Peng, M. W., \& Deeds, D. (2013). Venturing from emerging economies. Strategic Entrepreneurship Journal, 7(3), 181-196.

Yamakawa, Y., Peng, M. W., \& Deeds, D. (2008). What drives new ventures to internationalize from emerging to developed economies? Entrepreneurship Theory and Practice, 32(1), 59-82.

Yamakawa, Y., Peng, M. W., \& Deeds, D. (2014). Rising from the ashes: Cognitive determinants of venture growth after entrepreneurial failure. Entrepreneurship Theory and Practice.

Yang, H., Sun, S. L., Lin, Z., \& Peng, M. W. (2011). Behind M\&As in China and the United States: Networks, learning, and institutions. Asia Pacific Journal of Management, 28(2), 239-255.

Young, M., Peng, M. W., Ahlstrom, D., Bruton, G., \& Jiang, Y. (2008). Governing the corporation in emerging economies: A review of the principal-principal perspective. Journal of Management Studies, 45(1), 196-220.

Zhou, J. Q., \& Peng, M. W. (2010). Relational exchanges versus arm's-length transactions during institutional transitions. Asia Pacific Journal of Management, 27, 355-370.

Zhu, Y., Wittman, X., \& Peng, M. W. (2012). Institution-based barriers to innovation in SMEs in China. Asia Pacific Journal of Management, 29, 1131-1142.

Zoogah, D., Peng, M. W., \& Woldu, H. (2013). Institutions, resources, and organizational effectiveness in Africa. Working paper. Jindal School of Management, University of Texas at Dallas. 
AUTHOR QUERY FORM

\begin{tabular}{|l|l|l|}
\hline & Book: RGSM-V016-3610902 & \multicolumn{1}{|c|}{$\begin{array}{l}\text { Please e-mail or fax your responses } \\
\text { and any corrections to: }\end{array}$} \\
& $\begin{array}{l}\text { Chapter: CH003 } \\
\text { Emerald } \\
\text { Fax: }\end{array}$ \\
\hline
\end{tabular}

Dear Author,

During the preparation of your manuscript for typesetting, some questions may have arisen. These are listed below. Please check your typeset proof carefully and mark any corrections in the margin of the proof or compile them as a separate list.

\section{Disk use}

Sometimes we are unable to process the electronic file of your article and/or artwork. If this is the case, we have proceeded by:

\section{Scanning (parts of) your article $\square$ Rekeying (parts of) your article}

Scanning the artwork

\section{Bibliography}

If discrepancies were noted between the literature list and the text references, the following may apply:

The references listed below were noted in the text but appear to be missing from your literature list. Please complete the list or remove the references from the text.

UNCITED REFERENCES: This section comprises references that occur in the reference list but not in the body of the text. Please position each reference in the text or delete it. Any reference not dealt with will be retained in this section.

Queries and/or remarks

\begin{tabular}{|l|l|l|}
\hline Location in Article & \multicolumn{1}{|c|}{ Query / remark } & Response \\
\hline AU:1 & $\begin{array}{l}\text { Please confirm whether the } \\
\text { hierarchy given to the headings is } \\
\text { correct. }\end{array}$ & \\
\hline AU:2 & $\begin{array}{l}\text { Please provide the volume number } \\
\text { and page range for reference "Vlcek, } \\
\text { 2013". }\end{array}$ & \\
\hline
\end{tabular}




\begin{tabular}{|l|l|l|} 
AU:3 & $\begin{array}{l}\text { Please provide the volume number } \\
\text { and page range for reference } \\
\text { "Yamakawa et al., 2014". }\end{array}$ & \\
\hline AU:4 & $\begin{array}{l}\text { Please provide the working paper } \\
\text { number for reference "Zoogah et al. } \\
\text { 2013". }\end{array}$ & \\
\hline
\end{tabular}

